\title{
Scientilif Note
}

\section{Anopheline species (Diptera: Culicidae) from the Maracá Ecological Station, Roraima State, Brazil}

\author{
Vera Margarete Scarpassa ${ }^{1 \otimes} \bullet$ \& José Ferreira Saraiva ${ }^{2}$
}

1. Laboratório de Genética de Populações e Evolução de Mosquitos Vetores, Coordenação de Biodiversidade, Instituto Nacional de Pesquisas da Amazônia, Manaus, Amazonas, Brazil. 2. Laboratório de Entomologia Médica, Divisão de Zoologia, Instituto de Pesquisas Científicas e Tecnológicas do Amapá, Macapá, Amapá, Brazil.

\section{EntomoBrasilis 14: e964 (2021)}

\author{
Edited by: \\ William Costa Rodrigues \\ Article History: \\ Received: 25.viii.2021 \\ Accepted: 08.xii.2021 \\ Published: 22.xii.2021 \\ Corresponding author: \\ Vera Margarete Scarpassa \\ ७vvera@inpa.gov.br \\ Funding agencies: \\ \& Ministério da Ciência, Tecnologia, \\ Inovações e Comunicações-Instituto \\ Nacional de Pesquisas da Amazônia
}

\begin{abstract}
Anopheline species were sampled in different ecotones at Maracá Ecological Station and in Cantá municipality, both in Roraima State, Brazil, in June 2016. Nine species were recorded. Six species belong to the subgenus Nyssorhynchus and three species to the subgenus Anopheles. The most abundant species collected were Anopheles triannulatus s.l., Anopheles nuneztovari s.l. and Anopheles oswaldoi species B. The remaining species had frequencies lower than $10 \%$. While A. triannulatus s.l. was the most frequent and the most widely distributed species in the studied area, Anopheles darlingi Root, the main malaria vector in the Brazilian Amazon region, was captured in two different ecotones and in low frequency. Our findings suggest that the risk of malaria outbreaks at Maracá Ecological Station may be low. This study also describes the first record of Anopheles costai Fonseca \& Ramos in Maracá Ecological Station, Roraima State, increasing the distribution range of this taxon.
\end{abstract}

Keywords: Anopheles; Brazilian Amazon; malaria vector; Maracá Island; species diversity.
Mas aracá Ecological Station occupies a river island in the municipality of Amajari, Roraima State, northern Brazil, and it is approximately $135 \mathrm{~km}$ from Boa Vista, capital of Roraima. Maracá Island was officially inaugurated as "Estação Ecológica of Maracá (EEM)" in April 1978 and covers an area of some 112,000 hectares. It is delimited by the division of the Uraricoera River into two arms around the island: the Santa Rosa arm to the north and the Maracá arm to the south. Both are difficult to navigate.

Maracá Island has transitional climate and is surrounded by two biogeographical boundaries: the Amazon Basin and the Guiana Shield, extended between the Amazon rainforest and natural savanna areas (EDEN \& McGREGOR 1998). Maracá Island is extremely rich in biodiversity, consequently it has hosted many national and international research projects involving scientists and students.

In Brazil, malaria transmission is mostly confined to the Amazon region, where substantial progress has been made towards disease control in the past decades. In this region, vector studies have been considered essential part to inform vector control strategies and evaluate their impact on malaria transmission (RocHA et al. 2020). These actions have resulted in decrease of this disease in recent years (MS 2020). Nevertheless, there are still many Amazonian municipalities with high indices of malaria transmission (MS 2020). In most this has been caused by anthropic actions and deforestation that have led to population increases of main malaria vector in the Brazilian Amazon, Anopheles darlingi Root (TADel et al. 2017; Arcos et al. 2018; Rocha et al. 2020). Despite this, the Maracá Island has not been a focus of malaria-related fieldwork, a source of potential concern, given the international nature of many of the study teams, increases the risk of disease dispersion.

The first and only study related to incidence and distribution of Anopheles species on Maracá Island was conducted from 1987 to 1988, where 97 collection points were sampled across the island (RODRIGUES \& TADEI 1998). Based on the captures of the adult and immature stages, the authors recorded 17 anophelines species, indicating a high overall species diversity at the site. Of the 17 species captured, Anopheles albitarsis s.l. was the most frequent (55\%) on the island.

The current study aimed to make a preliminarily estimate of the abundance and diversity/richness of Anopheles species collected in the different ecotones of Maracá Ecological Station, Roraima State (primary forest), and in secondary forest within Cantá municipality, three decades after the Rodrigues \& TADEI (1998)'s study.

In the current study, adult anophelines were sampled in four different ecotones (edge of the primary forest; primary forest-ombrophylous; forest fragment of Campinarana; forest fragment of Lavrado-Savanna) at Maracá Ecological Station, in June 2016 (Table 1; Figure 1). In addition, samples from three localities of Cantá municipality, situated approximately $30 \mathrm{~km}$ from Boa Vista, were included in this study (Table 1; Figure 1). Adult mosquitoes were captured using Shannon light traps, installed in forest, approximately between 6:00 pm and 10:00 pm. Captured anophelines were placed in collection cups and transported live to polystyrene boxes to the Base Laboratory of the Island, where they were stored overnight. The next morning, approximately $25 \%$ of the collected female mosquitoes were individually separated into small oviposition cups and the offspring each progeny were reared to adulthood for morphological analyses. The 
Table 1. Anopheline species collected in the Ecological Station of Maracá and Municipality of Cantá, State of Roraima, Brazil.

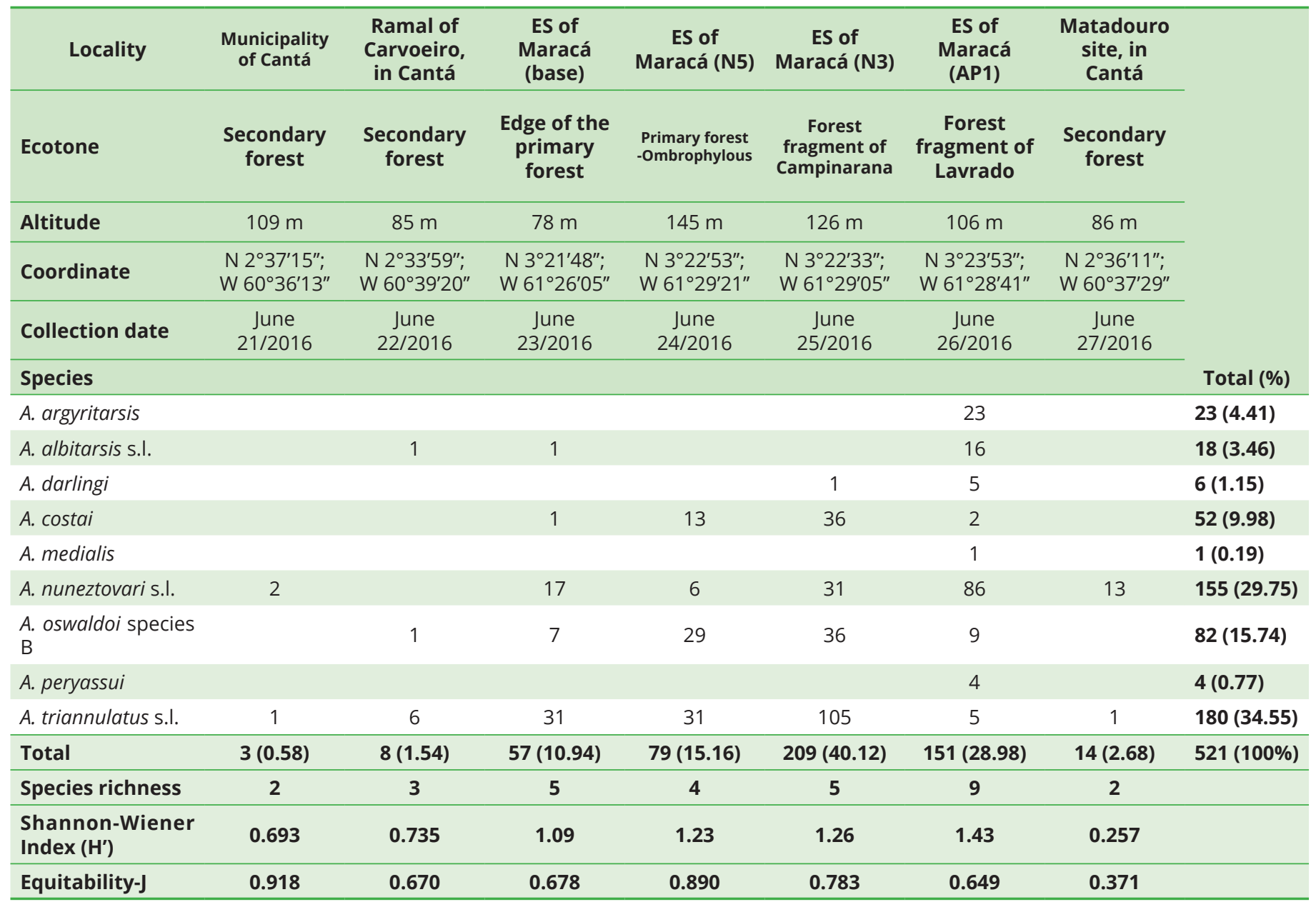

The numbers within parenthesis represent the percentage (\%). ES = Ecological Station. A. medialis, Harbach 2018 (A. medialis=A. intermedius).

remainder were preserved in a solution of $95 \%$ ethanol and stored at $-20{ }^{\circ} \mathrm{C}$ for molecular studies at the Laboratório de Genética de Populações e Evolução de Mosquitos Vetores, Instituto Nacional de Pesquisas da Amazônia, Manaus, Brazil.

In the municipality of Cantá, specimens were captured in secondary forest environments that had suffered some form of anthropic impact. All mosquitoes were captured using Shannon light traps, between 6:00 pm and 10:00 pm. Collected mosquitoes were preserved in 95\% ethanol and stored at $-20{ }^{\circ} \mathrm{C}$. The taxonomic keys of FARAN \& LINTHICUM (1981) and FORATTINI (2002) were used for morphological identification. Anopheles costai Fonseca \& Ramos was identified using male genitalia of offspring reared in insectary at the Laboratório de Genética de Populações e Evolução de Mosquitos Vetores, INPA, Manaus, Brazil (Figure 2).

Molecular identification was performed only for specimens from the A. oswaldoi complex, using the mitochondrial DNA (mtDNA) Cytochrome Oxidase, subunit I (COI) gene barcode region. Generated sequences were then compared with those deposited in GenBank; results indicated the presence of Anopheles oswaldoi species B in the area: an as-yet undescribed taxon in the $A$. oswaldoi complex (Ruiz-López et al. 2013; SARAiva et al. 2018). Collections were authorized by the Biodiversity Information and Authorization System (SISBIO), with permanent license number 38440 awarded to VMS. The analyses of richness, Shannon index and equitability-J were conducted in the Paleontological Statistics Software (HAMmER et al. 2001).

In the current study, a total of 521 mosquitoes were collected and identified, comprising nine Anopheles species (Table 1). Of these, six belonged to Nyssorhynchus subgenus: Anopheles argyritarsis Robineau-Desvoidy, Anopheles albitarsis s.l., A. darlingi, Anopheles nuneztovari s.l., Anopheles oswaldoi species $\mathrm{B}$ and Anopheles triannulatus s.l. The three other species were members of the Anopheles subgenus: A. costai, Anopheles medialis Harbach ( $=$ A. intermedius) and Anopheles peryassui Dyar \& Knab. The most frequently-caught species were of the subgenus Nyssorhynchus, which comprised 464 (89.06\%) of the captured mosquitoes. Anopheles triannulatus s.l. comprised $34.55 \%$ of the total individuals caught, followed by A. nuneztovari s.l. (29.75\%) and A. oswaldoi species B (15.74\%). The remaining species had capture frequencies lower than $10 \%$ (Table 1). All nine species were collected in the forest fragment of Lavrado, out of which three them (A. argyritarsis, $A$. peryassui and $A$. medialis) were exclusive of this ecotone. Unlikely, $A$. triannulatus s.l. was recorded in all the ecotones and at Cantá. Previous studies reported that $A$. peryassui, $A$. medialis and $A$. oswaldoi s.l. are often found in forest in the Brazilian Amazon and are predominantly zoophilic (TADEl et al. 1993, 1998; Barbosa et al. 2016). Our results support these findings.

The highest density (abundance) of specimens was observed in a forest fragment of Campinarana (white sand forest), comprising $40.12 \%$ of the total specimens collected. Anopheles darlingi was captured only in the forest fragment of Lavrado and forest fragment of Campinarana, but at very low frequency (five and one specimens, respectively). In the primary ombrophylous forest fragment - four species were collected, of which A. triannulatus S.l. and A. oswaldoi species $B$ were captured most frequently. At the primary forest edge, near the Base of Ecological Station of Maracá, five species were collected, of which $A$. triannulatus s.l. and $A$. nuneztovari s.l. were the most frequent (Table 1). 


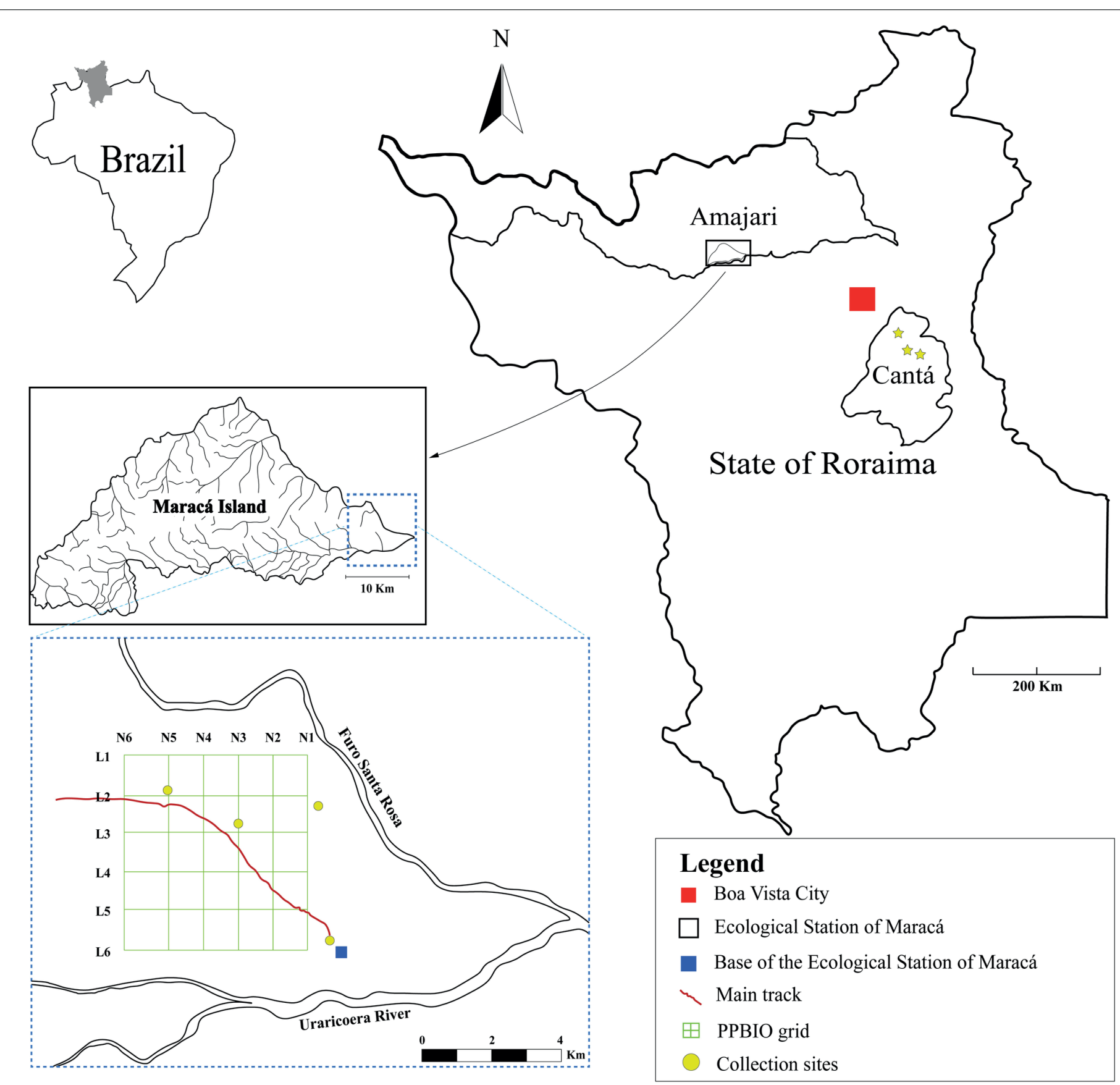

Figure 1. Map showing the collections sites of the Anopheline species in the Ecological Station of Maracá and Municipality of Cantá, Roraima State, Brazil.

Anopheles costai was found in the four different ecotones; however, it was the most frequent in the forest fragment of Campinarana (Table 1). Anopheles costai is morphologically very similar to Anopheles forattinii (Wilkerson and Sallum) and Anopheles mediopunctatus (Lutz) in the adult stage (NATAL et al. 2007). RODRIGUES \& TADEI (1998) registered A. mediopunctatus in Maracá; however, due to the high morphological similarity in the adult stage between these species, it is possible that the samples identified as A. mediopunctatus in the RODRIGUES \& TADEI (1998)'s study are in fact $A$. costai. Here, we initially identified these specimens as $A$. mediopunctatus based on the adult (females) collected in field. After to obtain the descendants reared in the insectary, they were identified as $A$. costai using male genitalia (Figure 2). The geographical distribution range of $A$. costai is poorly known in Brazil (NATAL et al. 2007). It was reported in São Paulo, Rondônia, Bahia, Minas Gerais and Pará States as well as in other South American countries. The first record of $A$. costai in the Ecological Station of Maracá as well as in Roraima State, increases the distribution range of this taxon.

In the three localities of municipality of Cantá, four species were captured: $A$. nuneztovari s.l., A. triannulatus s.l., $A$. oswaldoi species B and $A$. albitarsis s.l.; however, they were collected in frequency low. Anopheles triannulatus s.l. was registered in all localities.

Forested areas had higher Shannon Index values, indicating that they were more diverse. Forest fragment of Lavrado had the highest Shannon Index value, as it was there that the nine species were recorded. Campinarana and Lavrado forest sites were very close in terms of diversity. However, they were quite different from secondary forest areas, in Cantá (Table 1).

The current study showed that the highest species diversity/ richness and density (abundance) were observed in the forest fragment of Lavrado and Campinarana forest fragments, respectively. Anopheles nuneztovari s.l. was the most abundant species in the forest fragment of Lavrado, whereas in the Campinarana forest fragment, this was $A$. triannulatus s.I. In addition, $A$. triannulatus s.l. was captured in all collection points, and was thus the most widely distributed species and the most abundant anopheline species at both 


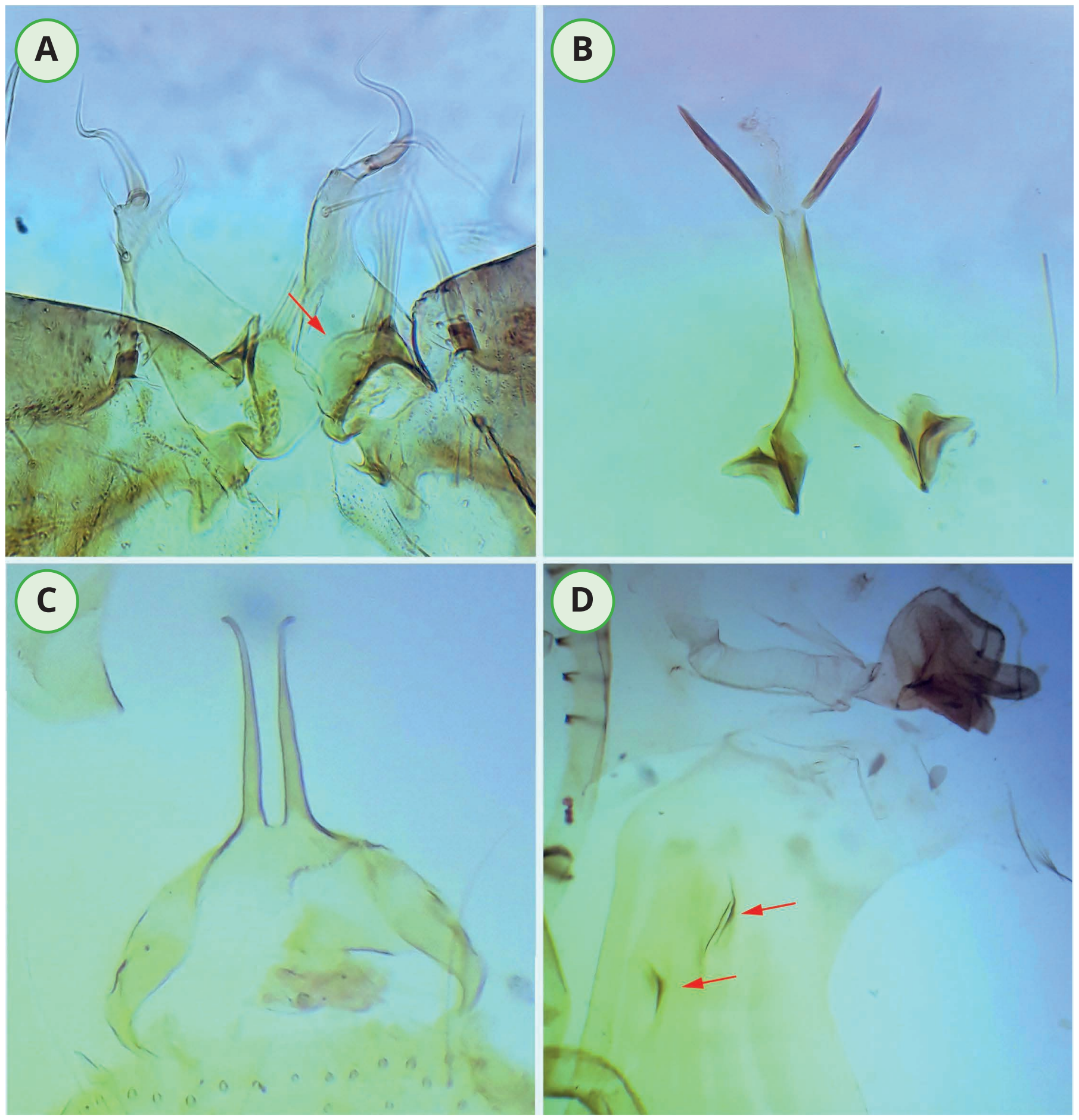

Figure 2. Morphological characters used in the identification of Anopheles costai. Specimens collected at ES of Maracá, municipality of Amajari, Roraima State, Brazil. A) Male genitalia showing the details of dorsal lobe with oval base (arrow), almost circular, B) Edeago with apical leaflets, C) Ninth tergal lobe of the male genitalia very close, long and parallel, D) Wing case of a pupa, showing two protuberances (arrows).

the Ecological Station of Maracá and Cantá municipality. In the Amazon region, this species has been reported from forest and edge of forest environments, as well as being captured in extradomiciliary environment and exhibiting zoophilic behavior (BARBOSA et al. 2016), which may explain the results of this study.

At Maracá, Rodrigues \& TADEl (1998) observed higher species diversity (17) than the current study (nine). These differences may be explained by the fact that these authors sampled a larger area of Maracá Island and analyzed a higher number of collection sites (97). In addition, the authors carried out captures during twelve months consecutives, encompassing the rainy and dry seasons.

However, both the current study and Rodrigues \& TADel (1998)'s reported $A$. darlingi in low frequency at Maracá. These results are in line with those observed by Hutchings et al. (2005;
2016) that in natural reserves and undisturbed forest areas from Amazon region, $A$. darlingi may be rare or absent. Nonetheless, many studies carried out in Amazon observed that this species easily adapts to the environmental changes and its immatures easily develop in artificial breeding sites, especially in fish farm tanks and/or fish ponds (ARCos et al. 2018; TADEl et al. 1998, 2017; RochA et al. 2020). However, while $A$. darlingi was not captured at the more disturbed habitats in Cantá municipality, the other species (A. nuneztovari s.l., $A$. triannulatus s.l., A. oswaldoi species B and A. albitarsis s.l.) were collected showed low frequency $(4.80 \%$ of the total captured, all three Cantá sites combined). This preliminary result is unexpected and further study is needed to explain them.

In the current study, A. albitarsis s.l. was sampled at low frequency (3.46\%), whereas in the Rodrigues \& TADEI (1998)' study it was the most frequent species (55\%) and showed little seasonal change. For the current study, collections were 
made only in June, so that no seasonal variability data exists. Previous studies conducted in Roraima have indicated that Anopheles marajoara and Anopheles janconnae, two members of $A$. albitarsis complex, should be regionally-important vectors of the malaria parasite (SILVA-VASCONCELOS et al. 2002; PóvoA et al. 2006). Currently, Albitarsis Complex comprises a 10 species-group (Мотокı et al. 2020), which are isomorphic or almost isomorphic species, as a consequence is extremely difficult to separate them without the use of molecular tools (Мотокі et al. 2020). As the molecular identification was not employed in this case, their accurate identify, and hence malaria-vectors, remains unverified

Our findings suggest that the risk of malaria outbreaks at the Maracá Ecological Station may be low. However, periodic entomological surveillance is recommended, because environmental changes in the area might occur which would favor the increase of vector species, especially $A$. darlingi.

\section{ACKNOWLEDGEMENTS}

This study was funded by MCTIC-INPA (grant number PRJ12.311), Brazil. The authors thank to Núcleo de Apoio à Pesquisa do INPA in Boa Vista, State of Roraima (headed by Dr. Reinaldo Ambrózio Barbosa) and ICMBIO-ESEC Maracá, in Boa Vista, State of Roraima (headed by Bruno de Campos Souza), Brazil, for the logistic support.

\section{REFERENCES}

Arcos, NA, FA Ferreira, HB Cunha \& WP Tadei, 2018. Characterization of artificial larval habitats of Anopheles darlingi (Diptera: Culicidae) in the Brazilian Central Amazon. Revista Brasileira de Entomologia, 62: 267-274. DOI: https://doi.org/10.1016/j.rbe.2018.07.006

Barbosa, LMC, RNP Souto, RMA Ferreira \& VM Scarpassa, 2016. Behavioral patterns, parity rate and natural infection analysis in anopheline species involved in the transmission of malaria in the northeastern Brazilian Amazon region. Acta Tropica, 164: 216-225. DOI: https://doi.org/10.1016/j. actatropica.2016.09.018

Eden, MJ \& FM McGregor, 1998. The Ilha de Maracá and the Roraima Region, p. 1-46. In: Milliken W \& JA Ratter (Eds.). Maracá: The Biodiversity and Environment of an Amazonian Rainforest. John Wiley \& Sons Ltd.

Faran, ME \& KJ Linthicum, 1981. A handbook of the Amazonian species of Anopheles (Nyssorhynchus) (Diptera: Culicidae). Mosquito Systematics, 13: 1-91.

Forattini, OP, 2002. Culicidologia Médica: identificação, biologia e epidemiologia: V. 2. EDUSP, São Paulo.

Hammer, Ø, DAT Harper \& PD Ryan, 2001. PAST: Paleontological Statistics Software Package for Education and Data Analysis. Paleontologia Electronica, 4: 1-9.

Harbach, RE, 2018. Culicipedia: Species-group, genus-group and family-group names in Culicidae (Diptera). Wallingford, United Kingdom: CABI.

Hutchings, RSG, MAM Sallum, RL Ferreira \& RW Hutchings, 2005. Mosquitoes of the Jaú National Park and their potential importance in Brazilian Amazon. Medical and Veterinary Entomology, 19:428-441. DOI: https://doi.org/10.1111/j.1365-2915.2005.00587.x

Hutchings, RSG, RW Hutchings, IS Menezes, MA Motta, MAM Sallum, 2016. Mosquitoes (Diptera: Culicidae) from the northwestern Brazilian Amazon: Padauari River. Journal of Medical Entomology, 53: 1330-1347. DOI: https://doi.org/10.1093/jme/tjw101

MS (Ministério da Saúde), 2020. Secretaria de Vigilância em Saúde. Boletim Epidemiológico. Número Especial. Novembro de 2020. 118 pp.

Motoki, MT, Y-M Linton, JE Conn, F Ruiz-Lopez, RC Wilkerson, 2020. Phylogenetic Network of Mitochondrial COI Gene
Sequences Distinguishes 10 Taxa Within the Neotropical Albitarsis Group (Diptera: Culicidae), Confirming the Separate Species Status of Anopheles albitarsis H (Diptera: Culicidae) and Revealing a Novel Lineage, Anopheles albitarsis J. Journal of Medical Entomology, 58: 599-607. DOI: https://doi.org/10.1093/jme/tjaa211

Natal, D, PR Urbinatti, RS Malafronte, HR Rezende, C Cerutti Jr. \& MAM Sallum, 2007. First record of Anopheles (Anopheles) costai Fonseca \& Ramos, 1939 in Espírito Santo State, Brazil. Revista do Instituto de Medicina Tropical de São Paulo, 49: 323-326. DOI: https://doi.org/10.1590/s003646652007000500009

Póvoa, MM, RTL Souza, RNL Lacerda, ES Rosa, D Galiza, JR Souza, RA Wirtz, CD Schlichting \& JE Conn, 2006. The importance of Anopheles albitarsis E and An. darlingi in human malaria transmission in Boa Vista, state of Roraima, Brazil. Memorias do Instituto Oswaldo Cruz, 101: 163-168. DOI: https://doi.org/10.1590/s0074-02762006000200008

Rocha, EM, RM Katak, JC Oliveira, MS Araujo, BC Carlos, R Galizi, FTripet, O Marinotti \&JA Souza-Neto, 2020. Vector-focused approaches to curb malaria transmission in the Brazilian Amazon: An overview of current and future challenges and strategies. Tropical Medicine and Infectious Diseases, 5: 161. DOI: https://doi.org/10.3390/tropicalmed5040161

Rodrigues, IB \& WP Tadei, 1998. Anopheles species of the Ilha de Maracá: Incidence and distribution, ecological aspects and the transmission of malaria, pp. 369-376. In: Milliken, W \& JA Ratter (Eds.). Maracá: The Biodiversity and Environment of an Amazonian Rainforest. John Wiley \& Sons Ltd.

Ruiz-Lopez, F, RC Wilkerson, DJ Ponsonby, M Herrera, MAM Sallum, ID Velez, ML Quiñones, C Flores-Mendoza, DD Chadee, J Alarcon, J Alarcon-Ormasa \& Y-M Linton, 2013. Systematics of the Oswaldoi Complex (Anopheles, Nyssorhynchus) in South America. Parasites \& Vectors, 6: 324. DOI: https://doi.org/10.1186/1756-3305-6-324

Saraiva, JF, RNP Souto, VM Scarpassa, 2018. Molecular taxonomy and evolutionary relationships in the OswaldoiKonderi complex (Anophelinae: Anopheles: Nyssorhynchus) from the Brazilian Amazon region. PLoS ONE 13: e0193591. DOI: https://doi.org/10.1371/journal.pone.0193591

Silva-Vasconcelos, A, MYN Kató, EM Mourão, RTL Souza, RNL Lacerda, A Sibajev, P Tsouris, MM Póvoa, H Momen \& MG Rosa-Freitas, 2002. Biting indices, host-seeking activity and natural infection rates of anopheline species in Boa Vista, Roraima, Brazil from 1996 to 1998. Memorias do Instituto Oswaldo Cruz, 97:1 51-161. DOI: https://doi.org/10.1590/ s0074-02762002000200002

Tadei, WP, JMM Santos, VM Scarpassa, IB Rodrigues, 1993. Incidência, distribuição e aspectos ecológicos de espécies de Anopheles (Diptera: Culicidae) em áreas naturais e sob impacto ambiental na Amazônia brasileira, pp. 167196. In: Ferreira, EJG, GM Santos, ELM Leão \& LA Oliveira (Eds). Bases Científicas para Estratégias de Preservação e Desenvolvimento da Amazônia. Instituto Nacional de Pesquisas da Amazônia, Manaus, Amazonas.

Tadei, WP, B Dutary-Thatcher, JMM Santos, VM Scarpassa, IB Rodrigues \& MS Rafael, 1998. Ecologic observations on anopheline vectors of malaria in the Brazilian Amazon. American Journal of Tropical Medicine and Hygiene, 159: 325-335. DOI: https://doi.org/10.4269/ajtmh.1998.59.325

Tadei, WP, IB Rodrigues, MS Rafael, RTM Sampaio, HG Mesquita, VCS Pinheiro, JAC Zequi, RA Roque \& JMM Santos, 2017. Adaptative processes, control measures, genetic background, and resilience of malaria vectors and environmental changes in the Amazon region. Hydrobiologia, 789: 179-196. DOI: https://doi.org/10.1007/ s10750-016-2960-y

$* * * * * * * * * *$ 

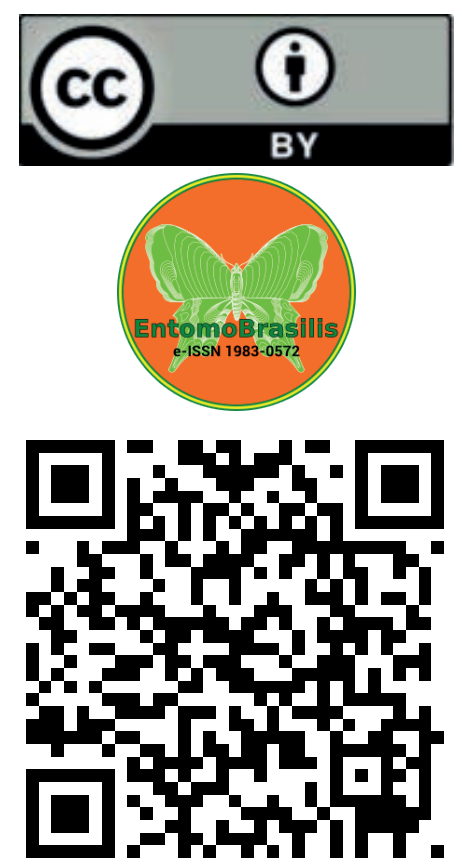